University). Dresser and Kossoudji's paper, "Why Did Women Retreai From the Industrial Labor Force in the Post World War II Period?," presented a statistical profile of the reasons for female departure from the Ford River Rouge factory. Smith's paper on "Farm Labor Organizing" suggested that the state's willingness to provide agribusiness with foreign labor effectively undercut the organizing efforts of the United Farm Workers. Finally, Heather Thompson's paper. "The "New' Industrial Workers and the Transformation of Organizing and Labor Relations, 1950-1980," contended that the leaders of the United Auto Workers cooperated with Chrysler to end militant protest by black workers between 1950 and 1973 and, consequently, led the union to accept reforms that weakened their position within the workplace. In her comments. Linda Blum (University of Michigan) concluded that the papers revealed the continued use of ethnic racial, and gender hierarchies to thwart workers' ability to control their labor.

Rather than being organized around any one particular topic or issue, the conference offered a variety of panels that addressed many of the current themes in the study of working-class history. This approach illustrated the ever-expanding focus of working-class history and its attempt to engage such issues as race. gender, immigration, and the state. Within this context the conference highlighted the continuing effort to understand the complexity of the world in which workers. their families, and the rest of society have interacted.

\title{
Colloquium on Popular Politics in the Netherlands, Sixteenth to Nineteenth Centuries
}

\author{
Maarten Prak \\ University of Utrecht
}

This colloquium, held on June 14, 1991 at the Netherlands Institute for Advanced Study in Wassenaar, was a follow-up to a meeting in September 1988 at the Lniversity of Leiden devoted to "Collective Action-Dutch reflections on the Work of Charles Tilly." This time, the focus shifted from riots, rebellions. and (potential) revolutions to the more general theme of popular participation in politics before the age of mass democracy. With this shift of emphasis, the organizers sought to explore, through the history of one particular part of Europe, the possibilities of an encompassing view of the role of subjects in a political system that denied them formal representation. The term "popular politics" was understood to include different forms of collective action, while taking into account other means of political expression by those formally excluded from participation in the system.

Wayne Te Brake's (SUNY. Purchase) introductory paper, "Reconstructing the History of Popular Politics in Europe, 1500-1850," set out to explore the theme 
from a theoretical angle. Te Brake defined "politics" as an "interactive bargaining process." By this definition a state's subjects always and automatically are included in any analysis of the political process. To trace the history of this aspect of early modern European history, according to Te Brake, is thus to ask for 1) an analysis of the structural elements determining the political process in general, and. more particularly, the process of state formation crucial for the period at hand; and 2) an explanation for the variations in popular political expressions and actions through time and space. Te Brake proposed to add the cultural system to the elements of warfare and economic structures stressed in Tilly's latest work on state formation. He also stressed the importance of two dimensions of political space: the extension of the domain in which political authority is being exercised, and the consolidation of that authority in sovereign rights.

Tiny Romme (University of Utrecht) provided a vivid picture of popular politics in the countryside of Dutch Brabant in his paper "Peasants, Politics and Protest in the Majory of Bois-le-Duc,.1770-1850." In the Dutch Republic, Brabant was exceptional in that it was directly subject to the States-General, whereas other territories exercised full political autonomy. Besides, Brabant was almost homogeneously Catholic in a country dominated by a Protestant elite that favored its co-religionists in Brabant by appointing them to office. These Protestant village officers could only operate. however, with at least some measure of compliance from the Catholic population. Besides, they resented the subject status of their province, and thus of their own offices. As a result, both Catholics and Protestants joined the revolutionary Patriot movement that spread throughout the whole of the Dutch Republic in the 1780s. The coming to power of these Patriots in 1794-95, in the wake of the invasion by a French revolutionary army, broke up the coalition in Brabant. Political discrimination against Catholics was formally abandoned, and they claimed most offices. Throughout the period, rural folk were active participants in local politics that had, together with similar activities in other parts of the country, repercussions on a national scale.

Paul Knevel (University of Amsterdam) presented some results of his research on urban militias in his paper "Citizens, Civil Guards, and Urban Politics in 17th Century Holland." These militias, or civic guards, were local civilian corps with military, ceremonial. and police duties. They also turned out to be a vehicle for the expression of popular demands. Throughout the seventeenth century, and especially in times of political crisis $(1609-21,1672)$, the militias presented petitions on behalf of the populace seeking to redress grievances. Every now and then, the presentation of such demands was backed up by the threat of arms that the militiamen were entitled to bear. From the middle of the century, the militias tried to disentangle their organizations from the powerful influence of local magistrates and obtain more direct control of them. Implementation of this demand, which continued to be raised during the eighteenth century, might have led to the recognition of a permanent form of popular representation within the Holland towns. As it was, the elites managed to stay in control, even if they sometimes had to call in the army to disarm the militiamen. 
Henk van Nierop's (University of Amsterdam) paper set out to show that although citizens of Dutch communities had no formal leverage over their rulers. they could and did exert considerable influence. through riots and rebellions, using the corporate institutions at their disposal, such as the guilds and the militias. In addition to such spectacular forms, there was an enormous amount of routine politics acted out through means of formal petitions presented by both institutions and individuals. The available evidence suggests that Dutch authorities spent a good deal of time carefully considering and answering such petitions. A major reason this routine "bargaining" was acceptable to both authorities and citizens was that all parties could subscribe to an ideology of "urban republicanism," a form of corporatism, albeit with differences of emphasis.

Charles Tilly concluded with comments on the day's proceedings and some "pressing questions" for further research. Linking the concept of democracy (along with "class," one of the words most conspicuously absent from the day's discussions) to the concept of citizenship, he asked whether the Dutch in fact were precocious in the development of citizenship and in the assertion of popular sovereignty, the extreme version of democracy. More broadly, he urged conference participants to investigate how political interactions between rulers and subjects produce changes in the state, how changes in political oppositions affect politics. and how the degree of popular sovereignty changes over time. Finally, Tilly asked why religious identities were so salient in the Netherlands, and how closely rights have been tied to religious identities in Dutch politics.

The papers by Te Brake. Romme and Knevel will be integrated into the book that each author is preparing. Van Nierop's paper will be published in a volume edited by Peter Blickle, in a series "The Origins of the Modern State in Europe." scheduled to be published in 1994 by Oxford University Press. 